\title{
O ÍNDICE AFETIVO DE ARTHUR LESS
}

\author{
ARTHUR LESS' AFFECTIVE INDEX
}

Ruan Nunes ${ }^{1}$

[https://orcid.org/0000-0002-5109-5199]

DOI: 10.30612/raido.v15i37.13974

RESUMO:O presente trabalho-índice oferece uma desleitura do romance As Desventuras de Arthur Less de Arthur Sean Greer ao propor uma investigaçăo sobre branquitude, cisgeneridade e heteronormatividade baseada em teorizaçōes sobre os afetos. Ao focar em afetos como felicidade, conforto e desorientaçăo, o índice destaca as relaçóes entre o protagonista do romance, Arthur Less, e o mundo que o cerca, propiciando uma discussáo das formas pelas quais ele é orientado para uma "vida boa" na qual valores brancos, cisgêneros e heteronormativos o impedem de pensar a sociedade na qual vive. Conclui-se que a elaboraçăo de um índice afetivo do romance possibilita um questionamento da estrutura que Arthur Less ignora, em especial, elementos que náo só visibilizam, mas questionam a branquitude e a cisgeneridade.

Palavras-chave: Teoria dosafetos;As Desventuras de Arthur Less; Branquitude; Cisgeneridade; Heteronormatividade.

ABSTRACT: This index-paper offers a misreading of Arthur Sean Greer's novel Less by proposing an investigation of whiteness, cisgenderness and heteronormativity based on affect theory. By focusing on affects such as happiness, comfort and disorientation, the index highlights the connections between the protagonist of the novel, Arthur Less, and the world surrounding him, making room for the discussion of the ways in which he is orientated towards a "good life" in which white, cisgender and heteronormative values prevent him from thinking about the society in which he lives. It is concluded that the development of an affective index of the novel makes it possible to question the structure which Arthur Less ignores, with special attention to elements which not only make whiteness and cisgenderness visible, but also question them.

Keywords: Affect theory; Less; Whiteness; Cisgenderness; Heteronormativity.

\section{Í DE ÍNDICE OU DE INTRODUÇÃO}

Sarah E. Truman (2019) descreve como um déjà-vu branco a sua sensaçăo de que, mesmo ensinando na Austrália, país com complexas relaçōes com sua história (pós-) colonial, as obras literárias utilizadas na escola para discutir questóes raciais eram marcadamente brancas e canônicas. Truman explica que nâo compreendia como um país com um histórico de questóes raciais como a Austrália utilizava um romance como

1 Doutor em Estudos de Literatura (UFF). Professor Adjunto de Língua Inglesa e Literaturas de Língua Inglesa da Universidade Estadual do Piauí, campus Parnaíba. E-mail: ruan@phb.uespi.br 
To Kill A Mockingbird ${ }^{2}$ para falar sobre racismo. A pesquisadora destaca que seu interesse náo é desmerecer a qualidade literária do romance escolhido, porém que sua preocupaçăo é a insistência em utilizar narrativas brancas nas quais sujeitos negros năo possuem agência sobre si quando poder-se-ia, por exemplo, falar sobre racismo usando obras produzidas no próprio país.

Para Truman, há uma lacuna na consideraçăo de obras para falar sobre racismo, afinal, ainda utilizam o romance supracitado para tratar de um tema caro às sociedades contemporâneas. Assim, Truman conclui que sua sensaçâo de déjà-vu branco é um efeito da branquitude operando sem questionamentos. Esse é o paradoxo que a própria autora detalha: "A branquitude é geral e específica, global e local, óbvia e escondida." (TRUMAN, 2019, p. 53, minha traduçăo) ${ }^{3}$ Como falar sobre racismo sem focar em sujeitos negros? Como falar sobre processos raciais sem citar os grupos que já săo tăo racializados nas mídias e nas artes? Como falar sobre racismo sem destacar sujeitos já tâo outremizados (BONNICI, 2007) em processos de exclusâo?

Concordo com Truman sobre o déjà-vu branco, mas discordo de sua decisáo sobre discutir racismo apenas a partir de obras de sujeitos negros ou indígenas. Escolher apenas obras de sujeitos minoritários como espaços de discussăo de determinados temas pode, infelizmente, repetir o padrâo de produçáo de exclusâo: a criaçấo tokenista de que apenas pessoas negras poderiam falar sobre o racismo, por exemplo. Surge daí uma indagaçâo sobre como falar sobre o racismo sem necessariamente destacar os processos de exclusáo que parecem assombrar as narrativas de grupos minoritários. Seria possível falar sobre racismo e racializar aquele que nâo é nomeado? Em outras palavras, como discutir o racismo que é "um problema branco" que "revela as ansiedades, hipocrisias e dois pesos da branquitude" (EDDO-LODGE, 2019, p. 182) sem colocar um peso nos ombros de populaçóes já precarizadas?

Buscando me aproximar dessas questóes no âmbito da literatura, proponho uma desleitura do romance As Desventuras de Arthur Less de Arthur Sean Greer. Em lugar de fechar o debate com definiçōes, essa desleitura, nutrida de um viés pós-estruturalista, busca ler o romance à luz da branquitude, da cisgeneridade e da heteronormatividade, discutindo como esse elementos estăo profundamente ligados aos campo afetivo. Parto de posiçóes que consideram os afetos como possibilidades críticas investigativas para sublinhar de que formas, por exemplo, a felicidade, a desorientaçáo e o conforto estâo socialmente ligados ao mundo da branquitude que nâo só nâo se racializa, mas também nâo se questiona como o centro discursivo de produçấo de sentidos. Cabe aqui apontar também que a própria ideia de uma desleitura é problemática por possuir distintas definiçôes nos campos literários. Parto aqui de duas possibilidades frutíferas de interpretaçáo: Harold Bloom (2003) e Juliana Cristina Salvadori (2017).

2 Doutor em Estudos de Literatura (UFF). Professor Adjunto de Língua Inglesa e Literaturas de Língua Inglesa da Universidade Estadual do Piauí, campus Parnaíba. E-mail: ruan@phb.uespi.br.

Traduzido no Brasil como O Sol é Para Todos, o romance é um dos mais populares nos contextos de Língua Inglesa, sendo inclusive parte de currículos escolares. Embora seja uma narrativa sobre injustiças sociais como estupro e racismo, o romance possui uma voz narradora branca que discute a vida no sul estadunidense a partir da prisấo de Tom Robinson, um homem negro acusado de ter violentado sexualmente uma mulher branca.

3 "This whiteness is general and specific, global and local, obvious and hidden." 
Conhecido nâo só pela produçăo crítica, mas também por declaraçôes controversas como a "escola do ressentimento", Harold Bloom (2003) utiliza o termo desleitura para pensar um alinhamento de influências entre poetas em Um Mapa de Desleituras. Já Juliana Cristina Salvadori, professora da UNEB, se apropria do termo para desenvolver uma açăo crítica na qual a desleitura, desligada de sua preocupaçáo apenas com a poesia, surge:

[...] como estratégia de resistência cultural, antídoto contra a angústia da influência, interpretada em uma chave pós-colonial: a desleitura póe em xeque a questáo de uma estética do novo, do original e nos permite repensar nossas experiências coloniais compartilhadas - mesmo que pontualmente diferentes - e lidar com a consequente angústia, como bem coloca Bloom (1991), de estar "atrasados" temporal e espacialmente excêntricos. (SALVADORI, 2017, p. 1795)

Dessa forma, a desleitura năo é apenas uma leitura interpretativa a partir da qual se desenvolve uma nova estética preocupada com as questōes atuais. A desleitura é em si uma tentativa de compreender, a partir de distintas interaçóes, as "experiências coloniais compartilhadas" na qual leituras contraditórias habitam o texto ao mesmo tempo que essa tentativa recusa uma chave interpretativa única e isolada. A desleitura aqui proposta é, sem dúvidas, uma interpretaçâo literária, porém uma que recusa o fechamento textual ora a partir de uma hermêutica de resgate, ora de uma hermenêutica da suspeita. Propóe-se questionar mais do que oferecer respostas, o que se torna produtivo dado o campo pouco espaço que estudos sobre a branquitude. (DEVULSKY, 2021)

Ao pensar o protagonista de As Desventuras de Arthur Less, proponho ainda desformatar um pouco a estrutura séria e acadêmica de artigos. Faço aqui um pequeno índice afetivo - incompleto, experimental e sem ordem alfabética - no qual algumas letras, afetos e elementos teóricos se fundem para possibilitar discussôes que recusam fechamentos ou finitudes. Dessa forma, pretendo desafiar o olhar objetivo que se pretende em investigaçóes acadêmicas ao traçar uma leitura que năo está necessariamente organizada como um documento científico tradicional. Parto do princípio que Arthur Less, o protagonista, está tanto no livro quanto nas realidades: é um personagem com o qual nos confrontamos constantemente, sendo necessário interpelá-lo pelo primeiro nome como estratégia de aproximaçăo. Dessa forma, Arthur Less se torna apenas Arthur, um sujeito do qual nos aproximamos como leitores e como sujeitos orientados em um mundo brancocêntrico.

Inicio agora o pequeno trabalho-índice.

\section{A DE AFETO}

Buscar uma definiçấo simples ou mesmo definitiva para afeto tem se tornado cada vez mais difícil. Brian L. Ott (2017, p. 1) aponta que "afeto é um conceito complexo e frequentemente controverso." Ann Pellegrini e Jasbir Puar (2009) sublinham as aparentes contradiçóes nos usos de afeto, sentimento e emoçăo. Teresa Brennan (2004) diferencia afeto de sentimento a partir da compreensâo de que o segundo é uma sensaçâo que possui uma expressâo em palavras em sua interpretaçâo enquanto o primeiro seria uma mudança fisiológica que acompanha um julgamento. Sianne Ngai 
(2005) sinaliza que a diferença entre afeto e emoçăo tem suas raízes nas práticas da psicanálise na elaboraçâo de representaçōes do sentimento em primeira ou segunda pessoa. À essa lista ainda podemos sinalizar as contribuiçôes de nomes canônicos já publicados no Brasil como Gilles Deleuze, Felix Guattari, Henri Bergson, Lawrence Grossberg, Brian Massumi, e aqueles que carecem ainda de espaços editoriais como Sara Ahmed, Eve Kosofsky Sedgwick, Ann Cvetkovich e Lauren Berlant, além dos citados anteriormente.

O que o parágrafo anterior náo consegue resumidamente dizer é que as definiçôes de afeto sâo múltiplas, complexas e até mesmo contraditórias. Dessa forma, ciente que este trabalho nâo poderá dar conta de todas as teorizaçôes, sublinho algumas tendências resumidas por Brian L. Ott (2017) sobre o que estamos falando quando falamos sobre afeto.

Em "Affect in Critical Studies", Ott (2017) aponta que existem três perspectivas dominantes no campo dos estudos afetivos. A primeira seria uma guiada pelas discussôes teóricas do psicólogo estadunidense Silvan Tomkins nas quais afetos săo compreendidos como estados elementares com base na psicologia e na neurociência. Nessa linha Teresa Brennan (2004) se encaixa por pensar os afetos como elementos que podem ser transmitidos. Já a segunda perspectiva pensa os afetos a partir de perspectivas psicanalíticas em diálogo com as ciências humanas. Aqui os afetos săo forças que podem ser aumentadas ou diminuídas, dependendo de como os corpos se encontram nos ambientes. É nessa linha que Deleuze e Guattari propóem que os afetos (ou afecçôes, terminologias ainda complexas em algumas traduçóes no Brasil) desafiam a virada linguística, tornando-se, portanto, experiências extralinguísticas que desafiam representaçōes. Contudo, tal compreensăo dos afetos como extensóes filosóficas têm gerado debates acerca de como eles poderiam ser políticos ou encorajar mudanças políticas pelo excesso de pensamento abstrato. Aqui, segundo Ott, é que a terceira perspectiva parece se delinear como uma prática crítica que Jenny Edbauer Rice (2008) chamou de "estudos críticos do afeto" - critical affect studies.

A terceira perspectiva se encontra "sentada no muro". Ela năo recusa assumir um lado; pelo contrário, em um movimento antropofágico, ela lê criticamente os ganhos e os desafios que cada perspectiva anterior possui para desenvolver uma leitura crítica de como os afetos podem ser mobilizados como açăo política na contemporaneidade. Nessa linha estăo, segundo Ott, Sara Ahmed e Gernot Böhme. Atuar nessa perspectiva dos estudos críticos do afeto é, portanto, situar uma compreensâo crítica de como pensar como os afetos náo sáo tăo autônomos assim - como Clare Hemmings (2005) expressa em sua dúvida sobre a "liberdade" dos afetos circularem aleatoriamente.

Hemmings escreve em "Invoking Affect" sobre sua reticência em aceitar que os afetos circulam livremente de corpo em corpo. Em outras palavras, Hemmings duvida da proposta de reinvençăo da roda que teóricos que trabalham com afeto propóem, sublinhando sua discordância, em especial, de Brian Massumi e Eve Sedgwick. Para ela, propor que os afetos sâo livres e que podem aderir aos mais variados corpos (pessoas, coisas, objetos, ideias, sensaçôes etc) é sugerir, inocentemente ou năo, que os afetos se "apegam" às coisas de maneira randômica - o que Hemmings lê como uma falha teórica, afinal, em apropriaçăo livre de Orwell, alguns corpos săo mais corpos que outros. Em outras palavras, afetos náo estăo dissociados de sentidos sociais porque eles existem justamente nas/pelas relaçôes sociais. Alguns corpos sâo mais definidos e associados 
por alguns afetos justamente porque existem em espaços sociais nos quais tais afetos os determinam. Penso aqui, por exemplo, na clássica associaçăo da raiva com mulheres negras (the angry black woman).

Nota-se, portanto, que definir o que seria afeto se apresenta como um desafio teórico, afinal, há pelo menos três perspectivas operando - uma na qual a ideia de estados elementares săo fixas demais, uma segunda na qual as definiçôes săo teóricas e abstratas em excesso, impedindo mobilizaçōes, e a terceira na qual busca-se um terreno em comum para operar criticamente. Alio-me aqui à terceira perspectiva justamente por compreender que teorizar sobre o afeto sem pensar questóes políticas e sociais năo poderia (me) mobilizar para açóes. Contudo, supor que as contribuiçóes das duas primeiras perspectivas năo săo válidas ou mesmo incompletas seria abrir măo da riqueza teórica das proposiçóes. Como Pellegrini e Puar (2009) afirmam, é a provocaçáo de todas essas abordagens críticas que possibilita uma expansáo do campo e mesmo uma mobilizaçâo para fins políticos - seja lá se usamos o termo afeto, emoçâo ou sentimento. Justamente por reconhecer as interseçôes entre as perspectivas, usarei o termo afeto como um guarda-chuva para abarcar o que alguns teóricos diferenciam como emoçăo ou sentimentos.

Desse modo, falar sobre afetos nesta desleitura é também se desfazer de posiçōes teóricas sólidas que pensam o afeto de formas abstratas ou fixas demais. Afeto é năo só aquilo que sentimos com palavras definidas, sentimentos para os quais verbalizamos frases que os explicam, mas também para as forças que nos mobilizam, positiva e negativamente, que nem sempre conseguimos transmitir verbalmente. $O$ que pensar sobre o afeto desafia aqui é uma compreensăo da razâo como elemento-chave universal, uma vez que, a partir de interaçóes entre discussōes feministas e LGBTQ+, qualquer noçăo do humanismo como nossa sólida formaçăo é questionada e tem suas inconsistências descortinadas. Desafia-se, como pensam Carolyn Pedwell e Anne Whitehead (2012), o hábito da observaçăo objetiva como modo de existência e coloca-se em destaque o emocional e o subjetivo como possíveis respostas.

O modo como conhecemos, experienciamos e vivemos o mundo é profundamente afetivo. $\mathrm{O}$ que aprendemos a amar e a odiar, a apreciar e a evitar săo resultados de nossas experiências afetivas, logo, nâo é possível pensar aqui que as formaçōes sociais e suas instituiçóes năo sejam também atreladas ao mundo afetivo. Deve-se pensar como esses espaços institucionais produzem, repetem e normalizam alguns afetos como certos ou errados, como possíveis ou impossíveis, como afetos que devemos sentir ou que devemos evitar. Engajar-se com essa produçăo afetiva é reconhecer quais objetos (pessoas, corpos, coisas, ideias etc) estăo afetivamente saturados e compóem nossas realidades. Ao desnaturalizar esses afetos, estar-se-ia desnaturalizando também o que compóe aquela realidade produzida. Năo é a tarefa das teorias críticas desnaturalizar ou desnormativizar essas realidades como materialmente produzidas por sistemas?

Antes de continuar com esse artigo-índice, é necessário deixar uma pergunta-norteadora: se afetos sâo partes integrais de nossas vidas, como é que esses mesmos afetos nos produzem e produzem o que sentimos? Será que esses afetos - bons ou ruins, bonitos ou feios, positivos ou negativos - podem se tornar espaços de produçăo de novos sentidos? Como que a desleitura de Arthur Less pode aqui sugerir que os afetos săo "cúmplices" da branquitude que năo se racializa? 


\section{B DE BOA VIDA OU B DE BRANQUITUDE}

Quem năo quer viver uma boa vida? Quem năo está sempre "lutando" por dias melhores? Será que as nossas escolhas sobre o que chamamos de "uma boa vida" nâo sâo também produçōes afetivas que mascaram e normalizam opressōes? Seria possível sugerir que essa noçâo de "uma boa vida" está afetivamente ligada à branquitude?

Lauren Berlant (2011) ajuda a pensar essa questăo ao cunhar o curioso conceito de otimismo cruel. Para a crítica, uma relaçăo de otimismo cruel, cruel optimism no original, "existe quando algo que você deseja é, na realidade, um obstáculo para o seu desabrochar." (BERLANT, 2011, p. 1, minha traduçăo) ${ }^{4}$ Em outras palavras, o que desejamos - as promessas de uma vida boa, a fantasia de ter uma vida de qualidade, um projeto político etc - se torna justamente aquilo que nos impede de alcançarmos o que desejamos. Berlant destaca que nâo săo esses desejos que sâo negativos ou cruéis per se, mas sim as relaçôes que eles estabelecem com nossas condiçōes.

Pensar que nossos desejos săo os próprios empecilhos no caminho parece ser um paradoxo, afinal, se eu desejo uma vida melhor é porque eu estaria, teoricamente, agindo para que essa promessa de vida se torne concreta. Contudo, essa promessa ou esse conjunto de promessas de "uma vida boa" é uma forma afetiva de desreconhecimento [misrecognize] que Berlant define como uma forma de atribuir sentidos afetivos a determinadas coisas por reconhecer que elas săo os objetos que desejamos. Na realidade, Berlant ressalta, é justamente esse desreconhecimento que faz sujeitos cada vez mais se alinharem aos ideias neoliberais de exploraçăo de si. Aí reside o otimismo cruel: como conseguir uma vida boa se estou constantemente me distanciando dela porque deixo para depois as perguntas sobre a crueldade do agora?

Ao sugerir que o otimismo cruel é uma ferramenta analítica que nos ajuda a pensar as formas afetivas pelas quais nos "apegamos" ao que chamamos de "uma boa vida" (BERLANT, 2011), podemos entâo destrinchar o que se espera dessas promessas de "uma vida boa": saúde, dinheiro, amor, paz? Cada item selecionado - e todos os outros năo selecionados - estăo imbuídos de promessas afetivas de que seremos felizes, mas na desleitura que faço de As Desventuras de Arthur Less localizo alguns: sucesso inigualável (porque Arthur Less náo se sente bem-sucedido), amor eterno (porque Arthur Less năo se sente amado), juventude permanente (porque Arthur Less se sente velho). Sucesso, amor e juventude săo as expressóes que fariam a vida de Arthur Less melhor, porém, para usar uma expressăo popular, "algo de errado nâo está certo": Arthur possui tudo o que deseja, mas năo consegue enxergar. Entăo, indaga-se na posiçăo de leitor: o que o impede de ser fez - bem-sucedido, amado e jovem? Em uma leitura otimistacruel, o que impede que Arthur se compreenda feliz é justamente o que ele é: um homem branco cisgênero de classe média. Em outras palavras, o privilégio de "uma vida boa" que ele recusa a enxergar e que busco problematizar aqui como sintomática da invisibilidade de discussōes de branquitude, cisgeneridade e heteronormatividade.

Descrito como uma comédia ou uma sátira por diversos meios de comunicaçâo, As Desventuras de Arthur Less recebeu o prêmio Pulitzer de ficçâo em 2018, consolidando a sua popularidade no meio literário. O romance apresenta a vida de Arthur

4 "Arelation of cruel optimism exists when something you desire is actually an obstacle to your flourishing." 
Less, um escritor náo muito famoso que está prestes a fazer 50 anos e decide viajar pelo mundo para náo ter que participar do casamento de um ex. Embora tenha um final feliz, As Desventuras de Arthur Less é um curioso romance no qual determinadas características do protagonista fomentam a desleitura que proponho.

Arthur avalia a sua vida como um grande fracasso, especialmente porque năo se compreende como uma pessoa amada por outras. Até entâo Arthur tivera dois relacionamentos longos - um com o famoso e premiado poeta Robert Brownburn e outro com Freddy Pelu, o primeiro bem mais velho que Arthur e o segundo bem mais novo. Ao receber o convite para o casamento de Freddy com outro homem, Arthur decide viajar porque náo desejar estar presente nessa cerimônia. Curioso pensar que ele precisa se fazer presente pela ausência, já que Freddy decidira convidá-lo mesmo após o término. O que segue em As Desventuras de Arthur Less é uma viagem na qual Arthur visita outros países para fugir do casamento do ex e "comemorar" o fracasso de ter 50 anos e nenhuma grande realizaçăo na vida. Sua primeira parada na viagem é o México para participar de um evento sobre os trabalhos do grupo artístico do qual seu primeiro companheiro, Robert, participara. Do México ele viaja para a Itália para receber um prêmio pela traduçăo de um de seus livros. Após o prêmio, Arthur atua como professor convidado em uma universidade na Alemanha e, por problemas de superlotaçáo no aviăo, ele aceita uma parada estratégica em Paris antes de seguir para Marrocos. Mais tarde, após Marrocos, Arthur reserva (erroneamente) um período em um retiro na Índia. Encerrando a sua jornada antes de retornar para Sáo Francisco, Arthur desembarca no Japáo para fazer um trabalho de crítica gastronômica para uma revista.

Percebe-se, observando o itinerário de Arthur, que ele năo é tăo fracassado como ele pretende ser. Suas viagens săo recheadas de pequenos acontecimentos e reviravoltas, incluindo pequenos affairs com outros homens - indo de um simples beijo em uma cobertura em Paris até uma relaçăo mais constante com Bastian durante o período na Alemanha. Além disso, Arthur recebe um prêmio pela traduçăo de seu terceiro livro, mesmo quando ele pensa que a tradutora fez um trabalho melhor ao "reescrever" a obra na traduçấo. Apesar de ter seu próximo livro recusado pela editora, Arthur ainda consegue ocupar determinados espaços que, embora ele considere menores, sáo espaços nos quais ser branco é a norma. Ao observar os outros finalistas do prêmio na Itália, por exemplo, Arthur marca a branquitude que o rodeia. Ao ser confrontado sobre seu próximo livro que narra a vida de "um homem gay de meia-idade caminhado por Săo Francisco [e] as tristezas dele." (GREER, 2019, p. 165), Arthur ouve uma desconhecida em Marrocos dizer-lhe que "é um pouco difícil sentir pena de um cara assim." (GREER, 2019, p. 165). Ao ouvir que seu alemáo é péssimo, Arthur se defende usando termos incompatíveis para a conversa que levam Bastian, seu amante alemăo, a dizer que Arthur "fala como uma criança. Você parece e age como uma pessoa muito nova. [...] Talvez você nunca tenha crescido." (GREER, 2019, p. 111)

$\mathrm{O}$ que as cenas anteriores e as que virăo a seguir indicam é a mais completa ausência de percepçăo da realidade que forma Arthur e essa ausência năo é apenas um pequeno acidente que torna o romance agradável. Pelo contrário, sugiro que é justamente essa ausência que torna o romance admirável: ao focar na mediocridade de um escritor que se acredita talvez injustiçado pela vida e pela sociedade, a branquitude se torna passível de análise. 
Recuso aqui tratar a branquitude como um sistema oposicional (brancos e negros como categorias fixas) porque As Desventuras de Arthur Less é um romance que desloca geograficamente, mesmo que ficcionalmente, a branquitude estadunidense de Arthur, em especial ao posicioná-lo em espaços como Índia e Japáo, comumente alocados como Ásia sem nenhuma consideraçâo geopolítica sobre as diferenças. Dessa forma, a branquitude que leio na obra é relacional porque ela assume diferentes formas em distintos momentos do romance, mas sempre operando para que Arthur se compreenda como um sujeito cuja vida é difícil, impedindo-o de conseguir pensar outras formas de se orientar.

Orientar-se como sujeito branco é, como sugere Sara Ahmed (2007), uma forma de reconhecer apenas as suas experiências como formas possíveis de existir. Em "Phenomenology of Whiteness" Ahmed retoma as discussōes de Husserl para teorizar como a branquitude é uma forma de orientar-se no mundo porque ela é uma "história em andamento e que náo terminou, uma que orienta corpos em direçóes específicas, afetando como eles 'ocupam' espaços." (AHMED, 2007, 150, minha traduçăo)5 Isso significa que o ato de orientar-se é baseado em perspectivas de determinados sujeitos, ou seja, no caso de Arthur e suas relaçôes com o mundo, é a perspectiva dele como sujeito branco, homossexual, cisgênero, de classe média que formula toda a sua orientaçăo no mundo. Ahmed năo é a primeira teórica a sublinhar a importância de atravessamentos e interseçóes entre gênero, raça, classe e sexualidade, porém, ela teoriza que a branquitude é uma herança dessas interseçōes justamente porque a forma como existimos no mundo é uma prática de criaçăo dele. Em outras palavras, ela indica que o mundo que construímos com nossas orientaçôes é o mundo que temos de herança de outras orientaçōes. Herdar o mundo de outras orientaçōes é, segundo a leitura de Ahmed, herdar a branquitude anterior disfarçada de outras formas. "A branquitude é apenas invisível para aqueles que a habitam," afirma Ahmed (2007, p. 157), "ou para aqueles que se acostumam tanto ao habitar que aprendem a năo ver, mesmo quando eles náo săo."6

Se a branquitude é, entâo, uma herança, uma forma de orientaçăo, faz-se necessário pensar de que formas desorientar-se seria uma estratégia para que corpos náo só ocupem espaços, mas principalmente os desocupem, como nos encoraja Sam Bourcier (2020). Desocupar é diferente de uma recusa de ocupar: é uma açâo política de compreender que apenas ocupar espaços pode ser uma armadilha assimilacionista na qual identidades dominantes mantêm seus jogos de poder intactos enquanto abrem espaços para aqueles que desejam ser acolhidos pela mesma rede de opressâo. Desorientar-se da branquitude é pensar quais as formas possíveis para desocupar lugares nos quais ela é invisibilizada. Uma possibilidade que me motiva é pensar como os afetos em As Desventuras de Arthur Less podem ser uma possibilidade de desorientaçăo, logo, pensar a desorientaçăo pode indicar possíveis caminhos de desocupaçấo da branquitude.

Será?

5 "Whiteness could be described as an ongoing and unfinished history, which orientates bodies in specific directions, affecting how they 'take up' space."

6 "Whiteness is only invisible for those who inhabit it, or those who get so used to its inhabitance that they learn not to see it, even when they are not it." 


\section{D DE DESORIENTADO}

A "boa vida" que Arthur Less năo consegue enxergar é a sua própria existência. Incapaz de refletir sobre as condiçōes de vida que outros năo possuem, Arthur pensa que sempre "estraga tudo. Estragou esse voo de Nova York para a Cidade do México, que ainda está prestes a piorar." (GREER, 2019, p. 48) Arthur é constantemente confrontado com uma versâo idealizada de vida à qual ele busca se apegar, porém nunca conseguindo perceber que as promessas de uma "boa vida" que ele idealiza nâo săo possíveis - nâo só para ele, mas para toda uma sociedade baseada em ideias heteronormativos fadados ao fracasso. Assim, Arthur acredita que viajar ao redor do mundo - um inegável privilégio - poderia "curá-lo" năo só da sua decepçâo amorosa, mas também de sua relaçâo com o mundo.

"Talvez Less sentisse, de fato, vergonha, como Finley Dwyer acusara." (GREER, 2019, p. 89) Sentir vergonha é uma resposta afetiva com a qual Arthur aceitara conviver. Finley Dwyer é um escritor gay que discursa na premiaçăo na Itália e sublinha como autores homossexuais escrevem livros tristes, encorajando a plateia a se rebelar contra tais "assimilacionistas que, no fundo, têm vergonha do que sâo, do que somos, do que vocês săo." (GREER, 2019, p. 88) Este discurso força Arthur a revisitar suas memórias, como em vários momentos no livro, para avaliar sua condiçăo de escritor. O que Arthur pensar "perceber" é que năo é visto como um nome de respeito, apesar de já ter publicado três livros e conseguido năo só prêmios, mas também sucesso. Dessa forma, uma estratégia de desenvolver empatia com Arthur seria a de compreender que ele está sofrendo uma crise criativa ou mesmo duvidando de sua capacidade como escritor, porém lembremos que aqui proponho uma desleitura, logo duvido de uma leitura empática na qual conteúdos como cisgeneridade e branquitude possam ser esvaziados em prol de uma leitura na qual todos seríamos humanos.

O sofrimento de Arthur, em minha leitura, năo deve ser invalidado. Contudo, há que se sublinhar que ele já publicara três livros, mesmo que com moderado sucesso, e conseguira levar uma vida tranquila e confortável em termos econômicos. As Desventuras de Arthur Less é um romance de ausência de consciência, uma sátira na qual a orientaçáo é branca. Quantos nomes de pessoas negras que escrevem conseguem descrever o mesmo cenário no qual Arthur se encontra? Um breve desvio aqui para auxiliar na desorientaçăo: em 2020 a hashtag \#PublishingPaidMe revelou chocantes (mas já esperadas) desigualdades no mundo da literatura. Nomes celebrados como Jesmyn Ward, ganhadora de dois National Book Awards, e N. K. Jemisin, ganhadora do prestigioso Hugo Award, revelaram ter sido pagas bem menos que outros nomes brancos. Esse breve desvio nos revela que Arthur, em sua condiçáo de escritor branco com moderado sucesso, conseguiu atingir determinados níveis pelos quais outros nomes negros ainda batalham. Náo se trata de desmerecer trabalhos ou hierarquizar qualidades, mas sinalizar que o cenário da literatura que faz Arthur duvidar de sua posiçăo como escritor nâo pode ser encarado como uma estratégia empática. Talvez uma saída para Arthur fosse pensar como a sua própria sala de concorrentes ao prêmio na Itália é marcada por sujeitos brancos. Esse primeiro passo na desorientaçăo poderia auxiliar na formulaçăo de um questionamento no qual a sua sensaçăo de desconforto origina năo necessariamente da percepçăo de escritor como fracasso, porém de uma estrutura na qual, para invisibilizar determinados sujeitos, Arthur precisa questionar sua própria qualidade para sustentar a invisibilidade dos outros. 
Para se desorientar, Arthur precisa mais do que apenas estar desorientado, como ele fica em sua viagem. Uma clássica forma de estar desorientado, no sentido de estar perdido, é náo falar a língua dos lugares, tarefa que Arthur "cumpre" muito bem em seu cristalino estado permanente de ignorância do mundo. Ao passear pelo México, Arthur exoticiza as ruas, esperando "túneis [no metrô] cheios de mosaicos astecas [mas] em vez disso, abismado, ele se vê numa réplica da sua escola de ensino fundamental, em Delaware." (GREER, 2019, p. 57) Na Alemanha, ao frequentar um bar e ver Bastian, seu amante alemáo, pela primeira vez, Arthur deduz que ele seria africano por causa de seus "belos traços negros e volumoso cabelo crespo." (GREER, 2019, p. 104). Para a surpresa de Arthur, Bastian é alemăo da regiăo da Bavária.

O que as cenas anteriores revelam é que Arthur Less é orientado pela sua ignorância branca, ignorância aqui compreendida no sentido delineado por Eve Sedgwick (1990) de que a ignorância é a ignorância de um conhecimento. Dizer que Arthur é ignorante năo é dizer que ele é um sujeito rude ou grosso. Pelo contrário, Arthur é desenhado como um amável homem que em breve fará 50 anos e precisa da empatia de leitoras e leitores para que sua tristeza seja compreendida como um sentimento universal. Como Zohra diz a Arthur no meio do deserto e afirmado anteriormente, é difícil sentir pena de um homem assim justamente porque ele se revela como um sujeito que náo se racializa para compreender o mundo - embora ele racialize o mundo constantemente.

Em uma de suas lembranças Arthur menciona que, em conversa com seu ex, năo gostaria de visitar o Taiti por ser "um lugar de resorts. Como se fosse impossível conhecer a populaçăo local. Eu quero ir para a Índia." (GREER, 2019, p. 162) Ironicamente, ao chegar à Índia, Arthur é confrontado com a "cômica" situaçaáo de ter reservado um espaço em um retiro cristăo no qual a simbologia cristă o cerca. Nấo bastando a sua ignorância em selecionar adequadamente um local de seu interesse na Índia, Arthur ainda se incomoda com a "algazarra própria à Índia: a competiçâo sonora espiritual." (GREER, 2019, p. 196) Ao reservar um retiro na Índia, Arthur seguira o conselho de um "rival" que é, na realidade, pai-tio de seu ex-amante Freddy. Entretanto, seria isso suficiente para perdoar sua escolha pela ignorância? Arthur reservara um local em outro país sem nem mesmo questionar ou buscar saber mais sobre o lugar, indicando sua escolha pela ignorância de outro conhecimento. Para tornar a situaçâo ainda mais "branca", Arthur já havia citado anteriormente que nâo escolheria ir para o Taiti porque gostaria de conhecer "a populaçăo local", um controverso sintagma do qual ele nem mesmo duvida do valor orientalista. Talvez, para desorientar-se, Arthur devesse pensar sobre a populaçăo local em Săo Francisco, onde mora. Será que eles também conseguem conceber quais corpos pertencem à cidade californiana na qual cada vez mais movimentos de gentrificaçăo expulsam corpos abjetos para receber de braços abertos outros "bons gays" homonormativizados?

Como diversos nomes têm teorizado, ser branco é a possibilidade de racializar o outro, ser o sujeito e náo o objeto em processos de outremizaçáo - processo de construçăo do Outro como "fora da normalidade" (BONNICI, 2007, p. 195). O que As Desventuras de Arthur Less potencializa satiricamente é a racializaçăo do sujeito branco que se compreende mediano em sua idealizaçâo de vida que também é, ou deveria ser ao menos, problematizada. AnnLouise Keating (1995) explica que é muito comum que se pense teórica e criticamente os movimentos de racializaçăo a partir 
da obra de sujeitos negros, indígenas, asiáticos etc, mas que o mesmo movimento sobre a branquitude ainda é pouco explorado como estratégia. Keating ilustra seu argumento citando o exemplo do Harlem Renaissance ser sempre citado como um movimento de artistas negras e negros, mas que năo usamos o termo "branco" para descrever o Transcendentalismo, movimento estadunidense no qual todos os sujeitos eram brancos e descendentes de europeus.

Keating năo se posiciona contra o uso de termos como negro ou asiático para discutir determinados espaços de produçâo cultural. Pelo contrário, ela enriquece o debate visibilizando questôes que já parecem cristalizadas e normalizadas aos olhos de muitas pessoas, gerando até mesmo discordâncias e temores infundados de que o "cânone" estaria sendo atacado. Dessa forma, Keating (1995, p. 904) sinaliza que "a branquitude tem funcionado como uma categoria pseudouniversal que esconde valores, epistemologias e outros atributos específicos sob o disfarce de uma 'natureza humana' nâo racializada, supostamente sem cor."7 A estratégia é, portanto, deslocar o foco da diferença como celebraçâo (WOODWARD, 2014), tema fundamental em muitos estudos pós-coloniais e/ou queer, para aquilo que é compreendido como norma ou padrăo.

Interrogar a branquitude em As Desventuras de Arthur Less permite questionar os espaços ocupados pelo protagonista e de que formas suas heranças invisibilizam sua orientaçáo. Um dos poucos momentos nos quais Arthur consegue se desorientar é quando entra no acampamento no meio do deserto enquanto viaja por Marrocos e surge uma faísca de desorientaçăo:

Ao entrar, Less náo consegue deixar de se perguntar: quem lustrou o espelho? Quem encheu o lavatório e limpou o vaso sanitário? E, já que começamos, quem trouxe essas camas de bronze para criaturas mimadas feito ele? Quem trouxe as almofadas e os tapetes? Quem disse: "É provável que eles gostem de colchas com espelhinhos"? (GREER, 2019, p. 172)

O que enriquece o questionamento é a ironia que está presente na ideia de que alguém decidira pelos hóspedes-turistas que "colchas com espelhinhos" agradariam, mesmo sem levar em consideraçăo quem estaria viajando. Arthur, contudo, observa partes do acampamento e se questiona sobre quem estaria por trás de todo aquele cenário fabricado para os olhos dos turistas. Parecendo temer demais o seu próprio questionamento, Arthur deixa de lado tais pensamentos e foca na beleza de estar ali no meio do deserto - "Obrigado, vida!" (GREER, 2019, p. 172) Aparentemente agradecer à vida é uma tarefa mais importante do que pensar sobre os espaços de opressáo e exploraçăo que ali residem, mas esse é Arthur Less. Săo escolhas brancas.

\section{F DE FELICIDADE COM S DE SOLIDÃO}

Se durante a viagem Arthur Less se depara com o seu "fracasso" como escritor, já havia uma certeza anterior: sua vida amorosa era um emaranhado sistema de conexóes

7 " [...] whiteness has functioned as a pseudouniversal category that hides its specific values, epistemology, and other attributes under the guise of a nonracialized, supposedly colorless, 'human nature'." 
instáveis. Todavia, assim como o seu fracasso profissional, sua vida amorosa parece ter um teor extra de sofrimento que năo condiz com a realidade. Mostrar-se como uma pessoa infeliz na vida amorosa é uma forma de criar pertencimento ao mundo cisheteronormativo no qual Arthur Less, mantendo intacto sua posiçâo de centro do discurso, consegue operar outras formas para se sentir "bem". Em outras palavras, ao dizer que está infeliz, Arthur está, na realidade, operando com a felicidade.

Ao dizer que está sozinho, Arthur está convenientemente esquecendo de que está rodeado de pessoas. A intençâo é criar um espaço de uma experiência universal comum a partir da qual a empatia seria uma estratégia de identificaçăo, afinal, quem nunca se sentiu sozinho após um término? Contudo, ao se deparar constantemente com pessoas que năo compartilham de sua visăo, Arthur se recusa a se "reorientar" porque isso significaria perceber o mundo de outra forma. Ao recusar se ver como o mundo o vê - dois exemplos: Zohra fala sobre náo sentir pena, Bastian o chama de infantil - Arthur consegue manter no lugar a sua infelicidade amorosa como um problema que ninguém compreende. Ele tâo cheio de amor e o mundo tăo incapaz de abraçá-lo. Por que Arthur insiste em se representar como um homem gay triste e infeliz? Será que essa infelicidade é um afeto que está sempre "grudado" em corpos gays? O que Arthur Less, em sua recusa em reconhecer que náo é um fracasso amoroso, pode nos dizer sobre excessos?

Seguindo o argumento de Sianne Ngai (2005) que aponta que corpos negros têm sido interpretados como afetivamente saturados de animaçăo [animatedness] por meio de uma perpetuaçáo de estereótipos, poder-se-ia argumentar o mesmo sobre corpos compreendidos como brancos, em especial homens brancos gays e suas relaçôes com tristeza/melancolia/infelicidade. Ao contrário das imagens que povoam o imaginário estadunidense em filmes e séries cada vez mais presentes nas mídias, Arthur năo é um "grande homem" - "Antes de mais nada, faltam-lhe os atributos físicos: ele é mediano em todos os sentidos. Um homem claramente americano, sorrindo e piscando com os cílios claros. Um rosto bonito, mas comum." (GREER, 2019, p. 112) Em As Desventuras de Arthur Less o corpo branco também é satiricamente lido como mediano, nada impressionante, comum, porém - e paradoxalmente - ainda branco o suficiente para ser objeto de desejo de Bastian, Javier, Freddy, Robert etc, alguns dos homens com quem Arthur se relaciona.

Brincando com percepçōes estereotípicas de sujeitos gays, As Desventuras de Arthur Less permite enxergar como os corpos brancos também recebem e produzem afetos, destacando como há uma produçăo de sentidos a partir de um lugar de privilégio naquele espaço. É essa relaçâo de produçâo de sentidos que Arthur ignora porque, caso ele a perceba, ele precisará repensar sua presença. O mundo de Arthur se orienta a partir de si e para si, repelindo qualquer outra visăo de mundo. É esse o eixo entre (in)felicidade e branquitude, uma porosa ligaçâo que absorve discursos normativos para produzir modos de ser feliz - e também razóes pelas quais pessoas săo infelizes.

Ser branco, Marcio de Abreu (2020, p. 33-34) afirma,

[...] em certo sentido e independentemente de escolha, significa personificar uma cultura que fala de si mesma, enquanto reivindica falar em nome de toda a humanidade, como se nâo houvesse qualquer especificidade racial ou cultural naquilo que, do colonialismo europeu, sobrevive de forma hegemônica no contexto pós-colonial. 
É essa ausência de consciência sobre a inexistência de uma experiência universal que guia Arthur Less. Poder se locomover por diferentes continentes, relacionar-se com diversos homens, conseguir ganhar prêmios, atuar em cursos após convite de universidades - tudo isso fortalece o sentido de que Arthur seria um único sujeito cujas experiências seriam universais. É essa problemática recusa em reconhecer outras expressôes étnico-culturais que impede Arthur de sair de sua zona de conforto. Essa recusa em reconhecer é uma forma de manter intacta a sua condiçăo de sujeito no mundo, afinal, abrir mâo de suas certezas colapsaria sua realidade e ele teria que refazer tudo dos cacos que sobraram. Como diz Grada Kilomba (2019, p. 75), "[a] branquitude é construída como ponto de referência a partir do qual todas/os as/os 'Outras/os' raciais 'diferem'. Nesse sentido, náo se é 'diferente', torna-se 'diferente' por meio do processo de discriminaçăo." Da mesma forma que tornar-se diferente é um processo de discriminaçấo, a felicidade é cúmplice do mesmo processo.

Ao tratar do fracasso amoroso, a narrativa em As Desventuras de Arthur Less năo deixa esquecer, por exemplo, que Arthur manteve alguns casos durante a viagem, contrariando sua lamúria de năo ser desejado. Pelo contrário, até o próprio Arthur, em breve surto de autoestima, se percebe "[m]ais bonito, mais seguro. A beleza da sua juventude de algum modo arrancada do depósito de inverno e devolvida a ele na meia-idade." (GREER, 2019, p. 135) O que isso diz sobre a ideia de felicidade que Arthur tanto nutre? De que formas a felicidade é produto dessa relaçăo coordenada afetiva que absorve algumas formas de felicidade e rejeita outras?

A felicidade como um afeto é compreendida aqui como uma intangibilidade porque sentir-se feliz é assumir que algo faltará justamente porque deslocamos nossos desejos para outros objetos. Dessa forma, estar feliz é algo circunstancial, algo temporário, algo que nos anima e também nos entristece. Teorizar a felicidade como afeto é compreender que é necessário ao mesmo tempo dialogar com a tristeza e/ou com a infelicidade.

Se ser feliz é ter o que queremos, logo estamos sempre infelizes porque sempre há algo que queremos e năo temos. Se essa ideia de felicidade é um diálogo com a tristeza, é possível pensar na inconstância de nossos sentimentos. Arthur, por exemplo, se sente triste porque náo acredita que será amado novamente e se sente decepcionado (com raiva também, talvez) quando descobre durante a viagem que um casal de amigos está se separando após 20 anos juntos. Lewis e Clark, o referido casal, estavam juntos há 20 anos e eram "o modelo de sucesso no amor." (GREER, 2019, p 160) Todavia, o que Arthur năo esperava era ver também tal idealizaçáo se desfazer. $\mathrm{O}$ amor eterno como um pilar para a felicidade é, portanto, desfeito.

Quando Lewis conta que ele e Clark estăo se divorciando porque foram felizes por 20 anos, Arthur se recusa a compreender, afinal, em sua opiniâo, "[a]lguma coisa deu errado." (GREER, 2019, p. 176) O que Arthur compreende por amor é a idealizaçấo de uma relaçăo entre duas pessoas, ignorando que ele mesmo, no passado, se recusara a participar de uma relaçăo "estável" com Freddy porque o segundo era bem mais jovem que Arthur. Para o protagonista do romance, sentir-se feliz é (também) ser amado dentro do contrato do amor como compromisso, o contrato do amor como casamento, uma forma heteronormativa de manter a felicidade como parte de um extrato das relaçóes. 
O amor como casamento é uma instituiçăo que, como sublinha Laura Kipnis (2004), está fadada ao fracasso pela sua obsessăo do compromisso com o compromisso. Kipnis escreve, em tons irônicos, sobre como o amor como uma instituiçấo social se revela uma forma de controle na qual a monogamia, o desejo e o casamento se tornam expressóes capitalistas de sujeiçáo moderna. Ao comparar a monogamia ao trabalho, o desejo ao contrato e o casamento a uma fábrica doméstica policiada com disciplina, Kipnis questiona - "É isso o que chamamos de uma ‘boa relaçâo'?"

A ironia de Kipnis ilustra como a ilusâo do amor que Arthur mantém é uma forma de controle social, em especial, uma forma de controle heteronormativo que recusa outras formas de relaçóes como possíveis. Arthur traía Robert, seu primeiro caso de longa data, enquanto estavam juntos porque sentia que precisava de algo mais por ser jovem e, ao se perceber ocupando a posiçăo de Robert em sua relaçăo com o mais jovem Freddy, sem dúvidas ele pensou que sofreria do mesmo destino. Essa paranoia sobre o amor e relaçóes é fruto de um controle regulado sobre as formas de felicidade. Nesse caso, estar infeliz năo é o mesmo que conseguir se desligar da estrutura que perpetua ideias heteronormativos de relacionamentos como o casamento e até mesmo a experiência das traiçôes. Em outras palavras, Arthur se sente infeliz justamente porque náo consegue abrir mâo da noçăo do amor como uma instituiçáo entre duas pessoas que deve ser eterno, passional e sempre surpreendente. É uma pena que um romance com sátiras e críticas ao modelo heteronormativo termine com um "final feliz" entre Arthur e Freddy: em uma virada positiva, o segundo percebe que năo conseguirá ser feliz no casamento, termina tudo e aguarda Arthur retornar de sua viagem de autoconhecimento.

As Desventuras de Arthur Less perdem uma grande oportunidade de quebrar com a ideia da felicidade gay como uma relaçăo entre duas pessoas ao abrir espaço para uma conciliaçâo heteronormativa extremamente palatável para públicos que "torcem" por finais felizes. Essa orientaçăo afirmativa de livros queer é uma polêmica que nâo abordarei aqui. Contudo, penso que perceber-se sozinho seria uma estratégia mais eficaz para Arthur conseguir se desfazer de sua concepçâo de amor idealizado. Pela solidăo Arthur conseguiria experimentar aquilo que nunca conseguira, afinal, sempre estivera em relacionamento, o que apenas informa que estar sozinho é um desafio para ele. Năo participar do jogo estabelecido de que o amor é, como na metáfora de Kipnis, uma fábrica doméstica policiada seria uma possibilidade de compreender que solidâo năo é o mesmo que infelicidade. Pelo contrário, repensar a felicidade como condicionada a determinadas estruturas sociais seria uma tentativa de usar a infelicidade como motor de novas formas de relacionamentos. É esse caminho que Lewis e Clark, o casal que se separa após 20 anos, está trilhando: recusando a ideia de que 20 anos juntos seria um fracasso, eles decidem terminar e continuar sua amizade. Arthur é incapaz de compreender essa construçâo porque sua vida foi e é integralmente regida pelo que Sara Ahmed (2010) chama de "scrips da felicidade" (happiness scripts) que săo descritos como "dispositivos de endireitamento" (straightening devices).

Ao se alinhar à felicidade heteronormativa branca, Arthur segue scripts de felicidade na qual determinados corpos sâo destinados à felicidade contanto que sigam determinadas formas de existir. Dessa forma, é possível pensar que o protagonista do romance, em seu pedestal de privilégios, nâo consiga conceber como outras pessoas 
podem desistir de relaçóes "felizes" enquanto ele, um merecedor (?), náo possui o que deseja. Embora Arthur náo articule em palavras tal afeto, compreendido como inveja talvez, suas açóes e escolhas denunciam sua aderência ao discurso heteronormativo. Talvez ficar sozinho - experienciar a solidâo - fosse uma tarefa mais revolucionária que apenas recusar a estrutura normativa do amor.

\title{
5. C DE CISGENERIDADE COM O MESMO C DE CONFORTO
}

\begin{abstract}
O Jardim dos Péssimos Gays. Quem poderia imaginar que uma coisa dessas existisse? Durante todo esse tempo, Less achou que fosse apenas um péssimo escritor. Um péssimo amante, um péssimo amigo, um péssimo filho. Aparentemente, a situaçăo é mais grave; ele é péssimo em ser quem ele é. Pelo menos, pensa, voltando os olhos para o outro lado da sala, onde Finley diverte a anfitriă, eu náo sou baixo. (GREER, 2019, p. 143, grifos no original)
\end{abstract}

Ao ouvir que é um péssimo gay, Arthur náo compreende imediatamente o que significa isso. Pensara, como o trecho acima ilustra, que era péssimo em diversas coisas, mas jamais cogitara que era péssimo em ser quem era. Esse é outro marco instigante em As Desventuras de Arthur Less. Ao destacar a ironia de ser péssimo em ser quem é, há um inevitável questionamento do que seria ser um gay bom ou um gay péssimo, elaborando um panorama de como determinadas formas de existir e os espaços nos quais elas habitam estâo constantemente se alimentando - um nâo existe sem o outro e, enquanto nâo houve alguma interrupçăo do mecanismo de produçáo, noçôes essencialistas de ser um bom gay continuarâo no lugar.

Sam Bourcier (2020) destaca que gays e lésbicas tratados como "bons exemplos" sâo aqueles que buscam um lugar na engrenagem social, buscando assimilaçâo e coerência com o discurso vigente. Bourcier sublinha que năo haverá mudança social enquanto esses sujeitos - gays e lésbicas - perpetuarem a ideia de inclusăo como forma de existência:

Pedidos de inclusăo e de incorporaçaáo à naçăo ou de integraçăo republicana de gays institucionais e lésbicas que náo têm legitimidade representativa os colocam em posiçáo de pedir para serem reconhecidos pelas instituiçôes que produzem as desigualdades e as discriminaçóes que elas pretendem combater. (BOURCIER, 2020, p. 47)

Considerando os cenários LGBTQ+ atuais em países do ocidente, năo me parece arriscado dizer que, embora existam pessoas trans que se alinham ao ideais que Bourcier critica, a maioria desses grupos de gays e lésbicas institucionais seja composto de pessoas cis. Identificar de que formas a cisgeneridade - o reconhecimento e a compreensăo de si a partir do sistema sexo-gênero ao qual o sujeito fora assinalado ao nascer - opera para manter-se como invisível pode oferecer uma leitura do mundo a partir dos lugares inocupados por pessoas que náo sâo cis. Questiono, pois, as formas pelas quais a cisgeneridade, na sua expressăo de infelicidade com objetos escolhidos, é uma aliada da branquitude e da heteronormatividade em As Desventuras de Arthur Less. Em outras palavras, quero pensar as relaçóes complexas entre a cisgeneridade e a branquitude dentro de uma matriz que hierarquiza sujeitos de 
acordo com determinados ideias heteronormativos. Dessa forma, pode ser possível apontar que pessoas brancas e cis náo conseguem racializar ou questionar a matriz heteronormativa porque é essa mesma matriz que lhes dá o conforto e a segurança necessários para existirem como sujeitos válidos e reconhecidos pelo Estado. No caso do romance, Arthur nâo só é produto dessas relaçóes, mas as mantém no lugar ao năo questionar o próprio sistema porque está preocupado com seu sofrimento - lembro aqui do otimismo cruel como uma possibilidade analítica.

Sofia Favero e Paula Sandrine Machado (2020, p. 55) descrevem que cis é uma relaçâo de existência, "um processo de nomeaçâo da norma, um recurso que surgiu para nomear aqueles e aquelas tidos/as como habitantes dos centros de um determinado ideal regulatório." Ao chamar atençâo, assim como a branquitude, para uma problematizaçáo do que seria a norma, a cisgeneridade surge como um questionamento das relaçôes. Usar o termo cis aponta para uma quebra do conceito do centro como o padrâo. Em outras palavras, descrever alguém como cis é lembrar que essa pessoa, homem ou mulher, se identifica com o sistema sexo-gênero (năo necessariamente sexualidade) ao qual ela fora socialmente designada.

Descrever a cisgeneridade é uma estratégia de recusa de pessoas trans como o Outro da relaçăo. Assim como estudos sobre a branquitude têm buscado desnomatizar o mundo, falar sobre cisgeneridade é reconhecer as formas pelas quais as instituiçóes sociais sáo moldadas para determinados grupos, especialmente homens brancos cis. Recusa-se, portanto, a ideia de que existe um normal ao qual se deve ater, afinal, nâo existe normalidade e natureza quando conceitos ali trabalhados surgem de vieses pré-concebidos por aqueles que estudam os fenômenos. Fabricar novos sentidos é recusar a máquina social que devora e normaliza sujeitos, revelando os mecanismos de invisibilizaçâo pelos quais opera a cisgeneridade.

Sinalize-se aqui também que pensar a cisgeneridade vai além do individual, afinal, ela é também "uma estrutura social, política, econômica e epistêmica [...] uma estrutura hegemônica de pensamento [...]." (FAVERO; MACHADO, 2020, p. 53) Como uma estrutura que regula corpos, a cisgeneridade funciona em diálogo com a ignorância da branquitude, como discutido anteriormente, e com a heternormatividade, em especial aqui a ideia da felicidade como um elemento cultural.

Nâo se trata aqui de dizer que As Desventuras de Arthur Less deveria ter incluído alguma personagem trans para criar uma experiência da cisgeneridade. Pelo contrário, a própria ausência de pessoas trans no livro é uma forma de sinalizar que a cisgeneridade náo é em momento algum questionada. Um mundo no qual Arthur Less transita sem nenhuma interferência da norma apenas ressalta que, embora seja um homem gay e parte de um grupo historicamente oprimido, Arthur ainda mantém estreitos laços com a heteronormatividade. O romance opera, portanto, com dois gumes: retratar a experiência de um homem branco e gay ao mesmo tempo que náo destaca o lugar das interaçôes (invisíveis para muitos) entre cisgeneridade e branquitude no pertencimento de Arthur. A cisgeneridade mantém no lugar o acesso de pessoas que se identificam com o sexo assinalado no nascimento e os espaços habitados por pessoas cis se mantêm estáveis sem "perturbaçóes" de gênero e ou sexualidade justamente porque pessoas trans nâo estâo ali. Essa ausência de reflexâo de Arthur em relaçâo aos espaços que ocupa por ser um homem branco e cis o fazem esquecer de seu acordo tácito com a heteronormatividade como ferramenta de sobrevivência. 
Michael Warner (1991) indica que a heteronormatividade é um lugar de violência a partir da normalizaçáo das relaçōes (afetivas, sexuais etc) dentro de uma matriz heterossexual. Sendo uma estrutura que nem sempre é questionada, nota-se que muitas pessoas LGBTQ+ acabam se associando ao mundo heteronormativo pelas suas condiçôes de espaços de privilégios - ou mesmo porque săo co-optados por discursos neoliberais de promessas de felicidade. Arthur Less está na interseçáo dessas duas avenidas.

Como Carlos, o pai de Freddy e "rival" de Arthur, diz em determinado momento: "Você tem uma vida melhor que qualquer pessoa que eu conheço." (GREER, 2019, p. 218) Arthur, obviamente, reage negativamente ao comentário - "Isso é absurdo para Less." (GREER, 2019, p. 218). Sua reaçâo indica sua ignorância sobre a sua situaçâo de privilégio, afinal, Arthur ainda se recusa a pensar que năo é necessariamente a pessoa fracassada que o sistema o faz acreditar. Aqui é onde é possível localizar a relaçâo entre cisgeneridade, heteronormatividade, (in)felicidade e conforto.

Ao năo pensar sobre sua situaçâo de privilégio, Arthur permanece intocável na sua zona de conforto. Seu sofrimento, para ele, é necessariamente a incapacidade de ser um bom escritor e também um bom gay, afinal, fosse ele bom nos dois âmbitos, ele teria uma carreira de (mais) sucesso e uma vida amorosa estável. Reside aí um sério problema com os objetos de desejo ao qual estamos afetivamente ligados: a felicidade só será possível quando determinados objetos estiverem ao meu alcance. Como Ahmed diz em "Phenomenology of Whiteness", a branquitude é uma herança de proximidade com alguns objetos, porém o que acontece quando pessoas brancas năo conseguem (também) ter mais essa herança porque vivem(os) num sistema que cada vez mais manipula as pessoas em suas vidas precárias? Quando Arthur náo consegue compreender que possui privilégios pela sua condiçăo de homem branco cis, ele ignora qualquer outra possibilidade de reorientar-se, consequentemente também negando que as condiçóes para outras pessoas năo săo as mesmas.

Ilustro novamente com as reaçóes negativas que Arthur tem quando ouve que Lewis e Clark estâo se divorciando e também quando escuta de Carlos que sua vida é melhor que a de muitas pessoas. Năo sugiro que Arthur năo possa estar infeliz e transformar esse afeto em um espaço de novas ambiçōes, porém, em uma desleitura como "resistência cultural" (SALVADORI, 2017, p. 1795), quero pensar o que năo se questiona pela possível empatia que Arthur desperta na audiência. A infelicidade de Arthur seria um espaço muito mais produtivo caso ele conseguisse utilizar sua constelaçăo de afetos para questionar a sua própria infelicidade com um sistema que o força a se encaixar em moldes de sucesso e amor enquanto o torna insensível às questóes do mundo, chegando ao ponto de ser racista e orientalista com seus comentários "engraçadinhos" sobre um negro na Alemanha, um metrô no México ou mesmo religiōes na Índia.

Ao seguir os scripts de felicidade estabelecidos pela sociedade, Arthur permanece como um sujeito que năo se racializa (mas racializa os outros), que náo se questiona (mas questiona os outros). Como lembra Sara Ahmed (2010), a felicidade pode operar para esconder a infelicidade justamente porque caso a segunda consiga emergir, algo na estrutura terá que ser questionado e mudado. Dessa forma, a aliança entre um sistema que constrói sujeitos dentro de uma matriz heternormativa se beneficia da ignorância sobre privilégios que é sustentada pela ausência de reflexâo crítica da 
branquitude e da cisgeneridade. Năo enxergar a sua orientaçăo no mundo é ignorar que existam outras orientaçôes ou mesmo definir quais orientaçôes sâo corretas. Năo é surpreendente, portanto, que ser um homem cis năo seja uma questăo para Arthur: ele năo se compreende como tal porque năo é necessário se questionar nessa particularidade. Possivelmente em algumas leituras, ele seria apenas um homem infeliz sofrendo por amor e todos nós sofremos por amor: o elo empático que permite disfarçar a jornada por um amor idealizado e impossível como o alvo da felicidade. Por isso torna-se vital questionar a cisgeneridade como uma produçâo de sentidos, especialmente no senso comum de que pessoas trans săo infelizes porque săo cooptadas por discursos desviantes enquanto pessoas (cis) săo felizes. Essa narrativa binária de tristeza/felicidade năo se sustenta mais e uma ferramenta que pode auxiliar na desconstruçăo desse senso comum é compreender a cisgeneridade como uma ferramenta que desloca sujeitos de seus espaços de conforto.

Embora pareça incongruente pensar em Arthur como um sujeito confortável, é essa imagem que desenho aqui. Falar sobre conforto năo é apenas conforto material, mas também o conforto que sentimos por sermos quem somos. Arthur pode se descrever como uma pessoa desconfortável e ouvir que é um péssimo gay, porém esses conteúdos náo o atravessam como pontes para mudanças. Pelo contrário, sempre que há alguma interaçâo que poderia interpelá-lo para pensar sobre sua condiçâo, Arthur se recusa a ouvir e reage, ora com pequenos comentários engraçados, ora com raiva e desprezo. Essa recusa náo é apenas uma dificuldade específica de Arthur, ela é sintomática do sistema no qual ele está incluído. Esse mesmo sistema informa Arthur que ele merece ser feliz enquanto afasta dele os objetos que ele deseja. Esse sistema informa Arthur que ele pode ser feliz, mas náo permite que ele questione que modelo seria esse de felicidade normativa. Uma felicidade baseada em "dispositivos de endireitamento" que buscam transformar sujeitos em pessoas "direitas", assimiladas.

Pessoas desconfortáveis gerariam linhas de tensăo que romperiam fios desse aparente belo tecido heteronormativo da paz social, logo, é essencial que as pessoas se sintam frustradas por náo se sentirem felizes porque náo conseguem ter aquilo que desejam. Pessoas infelizes aceitam o conforto que podem ter, mesmo que esse conforto seja o da ignorância. Ter "uma boa vida" é reconhecer alguns confortos e desejar outros: quem poderia culpar Arthur Less por năo se engajar com outras formas de pensar?

\section{T DE TERMINAR}

Durante um discurso público Paul Gilroy descreve cinco mecanismos distintos de defesa do ego pelos quais o sujeito branco passa a fim de ser capaz de "ouvir", isto é, para que se possa se tornar consciente de sua própria branquitude e de si própria/o como perpetradora/perpetrador do racismo: negaçâo; culpa; vergonha; reconhecimento; reparaçăo. (KILOMBA 2019, p. 43, grifos no original)

Grada Kilomba nos lembra que há um caminho que precisa ser trilhado para que de fato uma sociedade se compreenda como antirracista para além de filtros em redes sociais. Pensar em açôes antirracistas, no mundo dos estudos literários, significa ir além de açôes que destaquem as obras de escritoras e escritores negros. Um 
espaço antirracista também precisa questionar de que formas processos de racializaçăo operam em negociaçâo com a sexualidade, por exemplo. Ao compreender que a heteronormatividade está em constante diálogo com a branquitude e a cisgeneridade, será possível pensar em políticas de reorientaçâo, como sugerido anteriormente neste trabalho de índice.

Arthur Less ainda se encontra na fase da negaçáo. Negar é manter intacto seus privilégios, ignorar seus processos de racializaçăo e, principalmente, sustentar a fantasia da felicidade normatizada. Ler - ou melhor, desler - As Desventuras de Arthur Less é se aproximar do tom satírico e das armadilhas da empatia na literatura. Desler um romance aqui é uma tarefa difícil e complexa: como falar sobre cisgeneridade sem se apoiar na outremizaçâo de sujeitos trans? Como falar sobre branquitude sem cair na armadilha de teorizar sobre populaçôes negras, asiáticas ou indígenas, por exemplo? Desler é trabalhar com materiais literários comumente descritos como literatura norte-americana ou estadunidense (no caso do romance de Greer) e também colocar tais materiais como sintomáticos de uma ignorância de privilégios ou mesmo de um processo afetivo de associaçăo.

Pensar como os afetos sâo possibilidade investigativas em As Desventuras de Arthur Less é compreender que felicidade, solidāo, conforto e desorientaçâo podem estar socialmente relacionados com a branquitude e a cisgeneridade. Como afirma Clare Hemmings (2005), os afetos náo circulam livremente ou mesmo se prendem aos corpos e objetos de maneira randômica: eles sâo produzidos nas relaçóes. A felicidade, por exemplo, dialoga com a solidăo e o conforto quando sublinhei que Arthur mantém no lugar uma estrutura que o oprime dizendo que ele pode ser feliz caso atinja determinados objetivos, que nada mais săo do que elementos heteronormativos que o deixam cada vez mais infeliz pela impossibilidade. É esse otimismo cruel que Lauren Berlant cita: aquilo que desejamos é o obstáculo para nossa felicidade. Uma "boa vida" năo é possível nem mesmo para sujeitos brancos cis, como Arthur Less consegue exemplificar, logo como ignorar demandas e outras populaçōes que questionam (e também, muitas vezes, reiteram) tal estrutura de opressâo?

Para terminar esse trabalho-índice, gostaria de indicar que As Desventuras de Arthur Less é deslido aqui como uma experiência afetiva para compreender o sistema de opressăo que mantém determinadas formas de existir como autorizadas enquanto invisibiliza os "dispositivos de endireitamento". Embora o romance tenha sua parcela controversa de indagaçôes - o final "feliz", a ideia de que um bom gay é otimista -, é uma obra literária que permite traçar indagaçóes que ainda carecem de espaços em alguns territórios acadêmicos. A experiência de forçar a noçăo de um artigo como um ensaio-índice é também uma forma de recusar uma aliança completa com sistemas acadêmicos que se recusam a pensar quem habita revistas e periódicos universitários. Tal qual Arthur, muitos espaços ainda se recusam a pensar suas branquitudes (porque sâo várias), ainda nâo reconhecem suas felicidades depositadas em ideias heteronormativos impossíveis e ainda reagem negativamente quando seus afetos sáo questionados: é ou nâo é um déja vu branco? 


\section{REFERÊNCIAS}

ABREU, Marcio de. Raça, transculturalidade e (entre)lugar de fala. In: NOGUEIRA, Gilmaro; MBANDI, Nzinga; DE TRÓI, Marcelo (Org.). Lugar de Fala: Conexóes, aproximaçōes e diferenças. Salvador: Editora Devires, 2020. p. 33-39.

AHMED, Sara. A Phenomenology of whiteness, Feminist Theory, v.8, n. 2, p.-149-168, 2007.

AHMED, Sara. The Promise of Happiness. Durham: Duke University Press, 2010.

BERLANT, Lauren. Cruel Optimism. Durham: Duke University Press, 2011.

BLOOM, Harold. Um Mapa da Desleitura. Traduzido por Thelma Nóbrega. Rio de Janeiro: Imago, 2003.

BONNICI, Thomas. Teoria e Crítica Literária Feminista: Conceitos e tendências. Maringá: EdUEM, 2007.

BOURCIER, Sam. Homo Inc.orporated: O triângulo e o unicórnio que peida. Traduçăo de Marcia Bechara. Sâo Paulo: n-1 ediçōes, 2020.

BRENNAN, Teresa. The Transmission of Affect. Ithaca e Londres: Cornell University Press, 2004.

DESVULSKY, Alessandra. Colorismo. Săo Paulo: Jandaíra, 2021.

EDDO-LODGE, Reni. Por que Eu năo Converso Mais com Pessoas Brancas sobre Raça. Traduçăo de Elisa Elwine. Belo Horizonte: Letramento, 2019.

FAVERO, Sofia; MACHADO, Paula Sandrine. Amapôas e bofes já estavam aqui: Reencontrando a cisgeneridade nos trópicos. In: NOGUEIRA, Gilmaro; MBANDI, Nzinga; DE TRÓI, Marcelo (Org.). Lugar de Fala: Conexōes, aproximaçōes e diferenças. Salvador: Editora Devires, 2020. p. 51-60.

GREER, Andrew Sean. As Desventuras de Arthur Less. Traduçăo por Márcio El-Jaick. Rio de Janeiro: Record, 2019.

HEMMINGS, Clare. Invoking Affect: Cultural theory and the ontological turn. Cultural Studies, v. 19, n. 5, p-548-567, 2005.

KEATING, AnnLouise. Interrogating “Whiteness," Deconstructing Race. College English, v. 57, n. 8, p. 901-918, 1995. Disponível em http://www.letras.ufmg.br/padrao_cms/documentos/profs/marcel/Silko.pdf. Acesso em: 30 dez. 2020.

KILOMBA, Grada. Memórias da Plantaçâo: Episódios de racismo cotidiano. Traduçâo de Jess Oliveira. Rio de Janeiro: Cobogó, 2019.

KIPNIS, Laura. Against Love: A polemic. New York: Vintage, 2004.

NGAI, Sianne. Ugly Feelings. Boston: Harvard University Press, 2005.

OTT,BrianL.AffectinCriticalStudies, OxfordResearchEncyclopedia of Communication, v. 1, n. 1, p. 1-26, 2017. Disponível em https://www.academia.edu/34096680/Affect_in_ Critical_Studies. Acesso em: 30 dez. 2020. 
PEDWELL, Carolyn; WHITEHEAD, Anne. Affecting feminism: Questions of feeling in feminist theory, Feminist Theory, v. 13, n. 2, p.115-129, 2012.

PELLEGRINI, Ann; PUAR, Jasbir. Affect, Social Text, v. 27, n. 3, p.35-38, 2009. Disponível em http://jasbirkpuar.com/wp-content/uploads/2018/08/st100_04_pellegrini-1.pdf. Acesso em: 30 dez. 2020.

RICE, Jenny Edbauer. The new "new": Making a case for critical affect studies. Quarterly Journal of Speech, v. 94, n. 2, p. 201-202, 2008.

SALVADORI, Juliana Cristina. Desescritas e desleituras contemporâneas: o autor e o leitor no jogo do texto. In: CONGRESSO INTERNACIONAL DA ABRALIC, 15, 2017. Anais... Rio de Janeiro, 2017. p. 1794-1805. Disponível em https://abralic.org.br/anais/arquivos/2016_1491263772.pdf. Acesso em 07 Jun 21.

TRUMAN, Sarah E. White déjà vu: Troubling the Certainty of the English Canon in Literary Education, English in Australia, v. 54, n. 3, p. 53-59, 2019. Disponível em: https://www. researchgate.net/publication/342764732_White_deja_vu_Troubling_the_Certainty_of_ the_English_Canon_in_Literary_Education. Ácesso em: 30 dèz. 2020.

WARNER, Michael. Introduction: Fear of a queer planet. Social Text, v. 1, n. 29, p. 3-17, 1991.

WOODWARD, Kathryn. Identidade e diferença: uma introduçāo teórica e conceitual. In: SILVA, Tomaz Tadeu; HALL, Stuart; WOODWARD, Kathryn. Identidade e Diferença: A perspectiva dos estudos culturais. Petrópolis: Editora Vozes, 2014. p. 7-72. 